\title{
Comparative Study on the Decolorization of Orange II by Zero-valence Tin in Citric and Hydrochloric Acids
}

\author{
Shizuo Nishide ${ }^{1} \&$ Makoto Shoda ${ }^{1}$ \\ ${ }^{1}$ Chemical Resources Laboratory, Tokyo Institute of Technology, Yokohama, Japan \\ Correspondence: Shizuo Nishide, Chemical Resources Laboratory, Tokyo Institute of Technology, RI-7, 4259, \\ Nagatsuda, Midori-ku, Yokohama 226-8503, Japan. Tel: 81-42-799-2230. E-mail: nishide.s.aa@m.titech.ac.jp
}

Received: December 6, 2011

Accepted: December 22, 2011 Online Published: April 24, 2012

doi:10.5539/eer.v2n1p1

URL: http://dx.doi.org/10.5539/eer.v2n1p1

\begin{abstract}
Zero-valence tin reductively degraded a persistent azo dye, Orange II to produce colorless aromatic amines. The effects of acid concentrations and initial Orange II concentrations on the decolorization of Orange II by tin in citric and hydrochloric acids were investigated. The decolorization reaction in citric acid was faster than that in hydrochloric acid at 2.5 and $5 \mathrm{mM}$ acid concentrations. The faster reaction would be related to the characteristic dissolution reaction of tin in citric acid. The first-order kinetic was applicable in citric acid over the examined range of $0.1-0.4 \mathrm{mM}$ initial Orange II. However, at more than $0.2 \mathrm{mM}$ initial Orange II the first-order kinetic was not applicable in hydrochloric acid and thus the relaxation first-order reaction kinetic was applied. The result that zero-valence-tin/citric acid system demonstrated successful decolorization in repeated use supports the possibility of its application for azo dye wastewater.
\end{abstract}

Keywords: Zero-valence tin, Orange II, decolorization, citric acid, hydrochloric acid

\section{Introduction}

One million tons of synthetic dyes are produced worldwide every year and mainly used in textile mills. As about $10 \%$ of these dyes are released to wastewater (Young \& Yu, 1997), treatment of dye wastewater has attracted attention not only from viewpoint of the local landscape but also because of potential toxic risks. In particular, azo dyes, which account for $60-70 \%$ of total dyes of all textile dyestaffs produced (Rodríguez Couto et al., 2002) are resistant to biodegradation by conventional aerobic activated sludge method (Shaul et al., 1991).

Although the physico-chemical methods, such as adsorption, chemical coagulation and electrochemical oxidation, are viable option for the elimination of azo dyes, these processes have major drawbacks. Coagulation-flocculation using lime, alum, polyelectrolyte and ferrous salts produces huge amount of sludge which poses handling and disposal problems (Vandervivere et al., 1998). Adsorption of dyes using activated carbon or membrane filtration costs high and these processes merely transfer the pollutants from one phase to another (Robinson et al., 2001). Electrochemical oxidation of dye wastewaters is slow process and process know-how is not fully understood (Mannu \& Chauhari, 2002). Other emerging techniques, such as Fenton's reagent $\left(\mathrm{H}_{2} \mathrm{O}_{2}+\mathrm{Fe}^{2+}\right)$, ozonation, UV irradiation and the combined use of these processes may have potential for azo dyes. However, such technologies usually involved complicated procedures or are economically unfeasible (Pearce et al., 2003).

Anaerobic biological treatment holds promise in providing a low cost to treat the textile effluent (Delée et al., 1998; Mannu \& Chauhari, 2002). Azo dyes are degraded to aromatic amines under anaerobic conditions, but further degradation of these compounds needs the aerobic condition. Thus, the use of anaerobic-aerobic sequential batch systems has been proposed (Delée et al., 1998; Van der Zee \& Villaverde., 2005). However, the decolorization efficiency remains unsatisfactory mainly because of poor decolorization reaction rates.

The utilization of heterogeneous zero-valence metals (ZVM) such as iron, zinc and tin for pretreatment of azo dyes prior to aerobic biological process is an alternative approach. ZVM are moderately strong reducing agents that are capable of reducing many environmental contaminants (Choi \& Kim, 2009). Zero-valence iron has been extensively studied with respect to the decolorization of azo dye (Cao et al., 1999; Feng et al., 2000; Nam \& Tratnyek, 2000; Mu et al., 2004; Zhang, 2005). However, zero-valence iron has some drawbacks in practical applications. Once $\mathrm{Fe}^{0}$ was in contact with air, its reducing reactivity was reduced (Cheng \& Wu, 2003), and 
color removal was decelerated especially in alkaline region of $\mathrm{pH}$ because the precipitate of ferrous hydroxide on the surface of iron occupied the reactive sites, blocking the electron transfer between $\mathrm{Fe}^{0}$ and azo dyes and then terminating the reaction (Zhang et al., 2005; Chang et al., 2006).

The use of zero-valence tin may be able to avoid the problem of iron process descrived above. So far, few research on the decolorization of azo dyes by zero-valence tin has been conducted. In a previous paper, we demonstrated the applicability of the two-stage-treatment of chemical reduction by zero-valence tin and biological oxidation of a persistent azo dye, Orange II (Nishide \& Shoda, 2011). However, the reduction of Orange II by tin was performed under strong acid condition ( $\mathrm{pH}$ 1.7) using hydrochloric acid. In our other paper, the decolorization of azo dyes was performed under weaker acid condition $(\mathrm{pH}$ 3) using citric acid than hydrochloric acid by PIP (Powder impact plating) tin ball which was tin-immobilized-material and the zero-valence tin in the structure of PIP tin ball was suggested to play a major role in the decolorization reaction (Nishide et al., 2010). Zero-valence tin /citric acid system is expected to be the potential application to the reduction of azo dyes. In this study, we compared the decolorization kinetics of Orange II by zero-valence tin both in citric acid and in hydrochloric acid and investigated the mechanism for the enhanced decolorization by tin in citric acid.

\section{Material and Methods}

\subsection{Materials}

An azo dye, Orange II (Tokyo Kasei Kogyo Co., Ltd.) was used without further purification. Zero-valence tin (trade name:Tin Drops, average density: $7.2865 \mathrm{~g} / \mathrm{cm}^{3}$, BET surface area: $0.0025 \mathrm{~m}^{2} / \mathrm{g}$ ), $p$-aminobenzene sulfonic acid (ABS) and citric acid were purchased from Kanto Chemical Co., Ltd., and 1-amino-2-naphthol $(1 \mathrm{~A} 2 \mathrm{~N})$ was purchased from Wako Pure Chemical Industries Ltd. These chemical reagents were of guaranteed reagent grade. Tin rod (diameter: $6 \mathrm{~mm}$, length: $160 \mathrm{~mm}$ ) was purchased from Alfer Aesar Co., Ltd.

\subsection{Decolorization Procedure by Zero-valence Tin}

Ethylene vinyl acetate copolymer (EVA) mesh bags containing 7 grams of zero-valence tin were hung in $100 \mathrm{ml}$ beakers. Dye solutions in citric acid or in hydrochloric acid $(100 \mathrm{ml})$ were added in these beakers to start decolorization reaction. All experiments were performed under stirring condition by magnetic stirrer at room temperature in ambient air.

\subsubsection{Effect of Acid Concentrations}

The decolorization reactions were performed at three acid concentrations of $2.5,5$ and $5 \mathrm{mM}$ in hydrochloric acid and citric acid. The initial Orange II concentration was $0.1 \mathrm{mM}$ in this series of experiments. The first-order reaction constants were determined from fifty minutes reactions. Open-circuit potentials (OCP) were measured at $2.5 \mathrm{mM}$ and $5 \mathrm{mM}$ acid concentrations as described in section 2.3 .

\subsubsection{Effect of Initial Dye Concentrations}

The decolorization reactions were performed at the initial Orange II concentrations of $0.1,0.2,0.3$ and $0.4 \mathrm{mM}$ in $5 \mathrm{mM}$ hydrochloric acid and $5 \mathrm{mM}$ citric acid. The first-order reaction constants were determined from fifty minutes reactions in hydrochloric acid and one hundred minutes reactions in citric acid.

\subsubsection{Effect of $\mathrm{pH}$ in Citrate Buffer}

Citrate buffers ( $\mathrm{pH} 2.8-5.5)$ were prepared by mixing $5 \mathrm{mM}$ citric acid and $5 \mathrm{mM}$ trisodium citrate. The decolorization was performed at each $\mathrm{pH}$ using $0.1 \mathrm{mM}$ Orange II.

\subsubsection{Repeated Decolorization of Orange II}

The repeated decolorization reactions were performed in $10 \mathrm{mM}$ hydrochloric acid and $2.5 \mathrm{mM}$ citric acid. The initial Orange II concentration was $0.1 \mathrm{mM}$ in this series of experiments. The first reaction was started as described in section 2.2., and then the reaction solution was replaced with a fresh dye solution every fifty minutes to resume the reaction. This procedure was repeated five times.

\subsection{Analysis}

Dye concentration of Orange II was determined by measuring maximum absorbance of the dye solution (485 $\mathrm{nm}$ ) with a spectrophotometer (UV-220 Shimadzu).

To identify decolorization products of Orange II by tin, HPLC analysis was performed with Jasco PU-980 delivery system equipped with a UV-VIS detector (875UV Jasco), column oven (TU-100 Jasco) and reverse phase C18 column (AG 120, $0.46 \times 15 \mathrm{~cm}$; Shiseido). Elution condition was as follows; first step; isocratic condition with $0.1 \mathrm{M}$ phosphate buffer ( $\mathrm{pH} 7$ ) for $5 \mathrm{~min}$, second step; $10 \mathrm{~min}$ linear gradient of $0.1 \mathrm{M}$ phosphate 
buffer $(\mathrm{pH} 7)$ and water-methanol $(1: 1 \mathrm{v} / \mathrm{v})$ at a flow rate of $1.0 \mathrm{ml} / \mathrm{min}$, final step; isocratic with water-methanol $(1: 1 \mathrm{v} / \mathrm{v})$ for $10 \mathrm{~min}$. Eluents were detected at $254 \mathrm{~nm}$.

To determine open-circuit potentials (OCP) of tin in citric acid and hydrochloric acid solutions, tin rod sample was used as a working electrode and $\mathrm{Ag} / \mathrm{AgCl}$ saturated electrode was used as a reference electrode. These electrodes were set in two acid solutions and the potentials were measured using a voltammeter (Model M-1082, Able).

The measurement of BET surface area of tin drops was conducted by Shimadzu Co., Ltd.

\section{Results and Discussion}

\subsection{Effect of Acid Concentrations}

Zero-valence tin decolorized Orange II in $5 \mathrm{mM}$ citric acid solution and HPLC of treated solution of Orange II by tin showed two new peaks attributed to two products. The two products were identified as $p$-aminobenzene sulfonic acid (ABS) and 1-amino-2-naphthol (1A2N) by comparing the products with authentic samples (Nishide et al., 2010). These aromatic amines were produced through the reductive cleavage of azo bond of Orange II as shown in Figure 1.

Time courses of the concentrations of Orange II and the products of ABS and 1A2N are shown in Figure 2. It was confirmed that decolorization reaction of Orange II by tin produced ABS stoichiometrically. However, the concentration of $1 \mathrm{~A} 2 \mathrm{~N}$ produced was lower than the stoichiometrically calculated value, mainly because of loss of $1 \mathrm{~A} 2 \mathrm{~N}$ by the autooxidation of $1 \mathrm{~A} 2 \mathrm{~N}$. The autooxidized products of $1 \mathrm{~A} 2 \mathrm{~N}$ were not confirmed because they were not detected by HPLC (Nam \& Tratnyek, 2000).
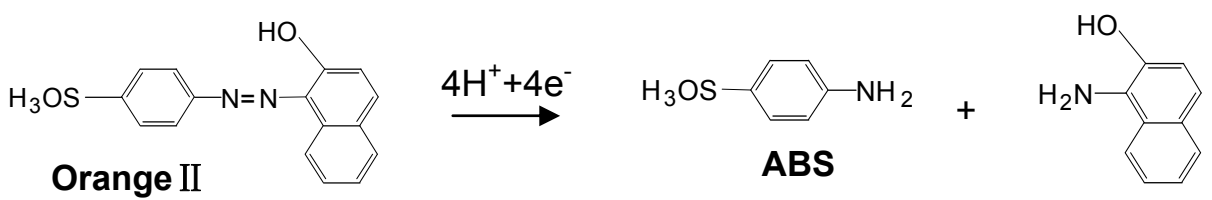

Figure 1. Reductive cleavage of Orange II by tin

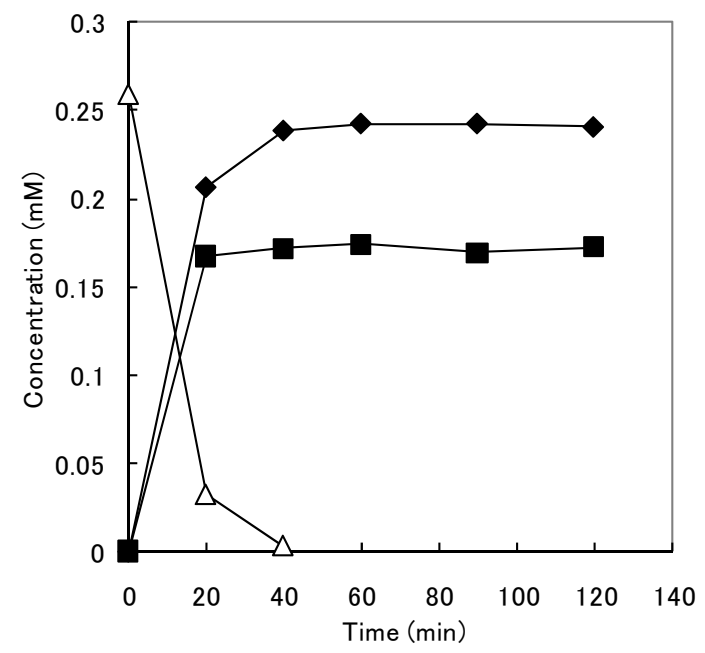

Figure 2. Time course of degradation of Orange II $(100 \mathrm{mg} / \mathrm{l})$ by tin $(7 \mathrm{~g})$ in $5 \mathrm{mM}$ citric acid aqueous solution (100ml, pH 2.8). $\triangle$ : Orange II, $\diamond: p$-aminobenzene sulfonic acid, $\mathbf{m}:$-amino-2-naphthol

Figure 3(a) shows the decolorization of $0.1 \mathrm{mM}$ Orange II by tin in $2.5 \mathrm{mM}$ citric acid and in $2.5 \mathrm{mM}$ hydrochloric acid. Tin/citric acid system showed significantly higher decolorization rates of Orange II than tin/hydrochloric acid system. No decolorization was observed in both acids in the absence of tin.

The time courses of open-circuit potentials (OCP) of tin during the experiments in Figure 3 (a) are shown in 
Figure 3(b). OCP is generated from the dissolution reaction of tin as follows.

$$
S n \rightarrow S n^{2+}+2 e^{-}
$$

The higher negative value of OCP was obtained in citric acid compared with that in hydrochloric acid.

At initial concentration of $0.1 \mathrm{mM}$ Orange II in Figure 3, decolorization reactions were expressed by the pseudo-first-order reaction (Equation 2)

$$
-d C / d t=k_{o b s} C
$$

Where $\mathrm{C}$ is the Orange II concentration $(\mathrm{mM})$, and $\mathrm{k}_{\mathrm{obs}}$ is the pseudo-first-order reaction rate constant $\left(\mathrm{min}^{-1}\right)$.

Integration of equation 2 gives

$$
\ln \left(C_{o} / C_{t}\right)=k_{o b s} t
$$

Where $C_{o}(\mathrm{mM})$ is the initial concentration of Orange II, and $C_{t}(\mathrm{mM})$ is the Orange II concentration at a reaction time $t(\min )$. A slope of straight line by $\ln \left(\mathrm{C}_{\mathrm{o}} / \mathrm{C}_{\mathrm{t}}\right)$ against $\mathrm{t}$, gives $\mathrm{k}_{\text {obs }}$. Table 1 shows the results of $\mathrm{k}_{\mathrm{obs}}$ calculated from eqn. (3) and the open-circuit potential (OCP) after $18 \mathrm{~min}$ from the start of experiments in the two citric and hydrochloric acid concentrations. When hydrochloric acid was increased from $2.5 \mathrm{mM}$ to $5 \mathrm{mM}$, the $\mathrm{k}_{\mathrm{obs}}$ value increased more than ten-fold and OCP value in $5 \mathrm{mM}$ hydrochloric acid was negatively higher by $40 \mathrm{mV}$ than that in $2.5 \mathrm{mM}$ hydrochloric acid. The similar trend was reported on the decolorization of Orange II by zero-valence iron in which the OCP showed a highly negative value at lower $\mathrm{pH}$ and the potential was closely related with the efficiency of decolorization of Orange II by iron (Mielczarsky et al., 2005). When the concentration of hydrogen ion increased, dissolution of zero-valence iron was thermodynamically feasible (Mu et al. 2004). In $10 \mathrm{mM}$ hydrochloric acid, the significantly higher value of $\mathrm{k}_{\mathrm{obs}}$ than 2.5 and $5 \mathrm{mM}$ was obtained (see Table 1). We did not measure OCP value at $10 \mathrm{mM}$ acid concentration, but we assume that the solution will show the higher negative OCP than those in 2.5 and $5 \mathrm{mM}$ according to the decolorization efficiencies.

The $\mathrm{k}_{\mathrm{obs}}$ values and OCP values were almost the same in different citric acid concentrations. The $\mathrm{k}_{\mathrm{obs}}$ values in tin/citric acid in 2.5 and $5 \mathrm{mM}$ were larger than those in tin/hydrochloric acid and OCP values in tin/citric acid were negatively higher by more than $100 \mathrm{mV}$ than those in tin/hydrochloric acid. The negatively higher values of OCP in citric acid were related to the formation of stable complex between tin and citrate (Gouda et al., 1981). Thus, shifting towards negative values of OCP indicates the increase in the energy of electrons generated from tin dissolution and the stronger reducing power of the electrons. This electrochemical behavior could be related to the enhancement of the reduction of Orange II in citric acid.
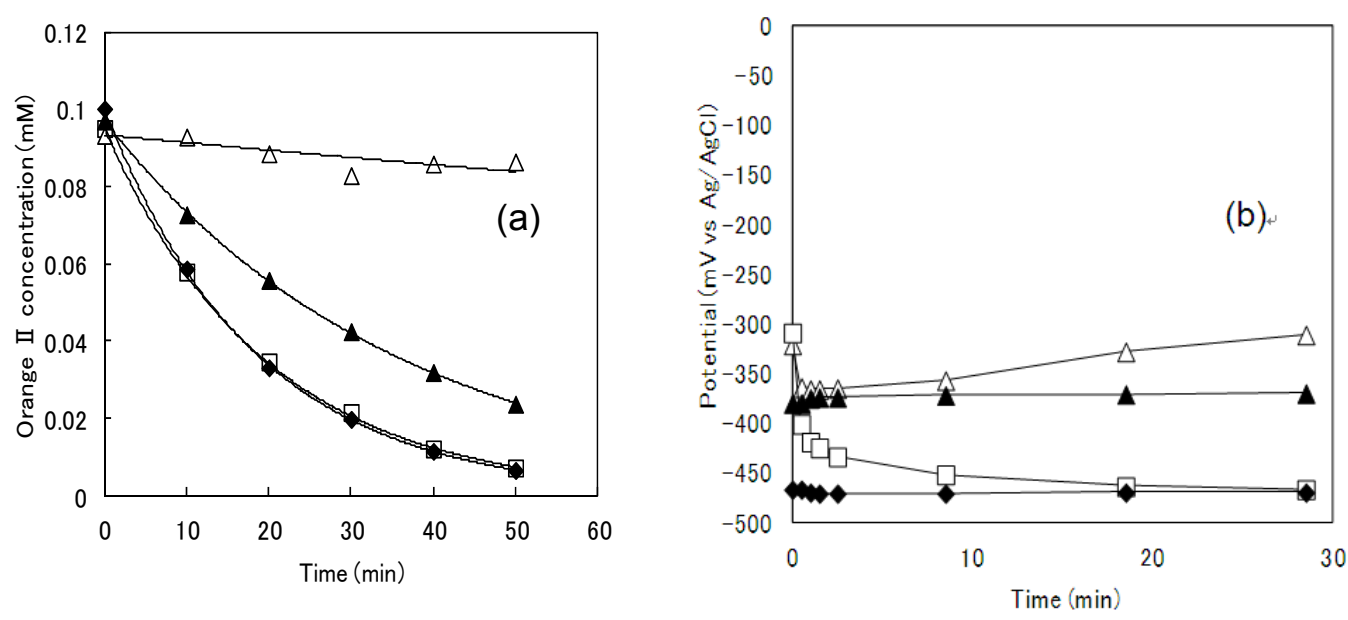

Figure 3. Decolorization of Orange II in citric acid and in hydrochloric acid. Time course of the concentration of Orange II (a) and open-circuit potential (b) at initial Orange II of $0.1 \mathrm{mM}$. $\square$ : $2.5 \mathrm{mM}$ citric acid, $\diamond: 5 \mathrm{mM}$ citric acid, $\triangle: 2.5 \mathrm{mM}$ hydrochloric acid, $\mathbf{\Lambda}: 5 \mathrm{mM}$ hydrochloric acid 
Table 1. First-order reaction rate constants $\left(\mathrm{k}_{\mathrm{obs}}\right)$ of decolorization of $0.1 \mathrm{mM}$ Orange II and open-circuit potential (OCP) in different acid concentrations

\begin{tabular}{ccccc}
\hline Acids & Acid conc. $[\mathrm{mM}]$ & Solution $\mathrm{pH}$ & $\mathrm{k}_{\mathrm{obs}}\left[\mathrm{min}^{-1}\right]$ & OCP $[\mathrm{mV}]$ \\
\hline Hydrochloric acid & 2.5 & 2.68 & $2.1 \times 10^{-3}$ & -328 \\
& 5 & 2.35 & $2.8 \times 10^{-2}$ & -370 \\
& 10 & 2.11 & $7.6 \times 10^{-2}$ & No measurement \\
Citric acid & 2.5 & 2.95 & $5.4 \times 10^{-2}$ & -464 \\
& 5 & 2.80 & $5.5 \times 10^{-2}$ & -470 \\
& 10 & 2.70 & $5.8 \times 10^{-2}$ & No measurement \\
\hline
\end{tabular}

\subsection{Effect of Initial Orange II Concentrations}

Plotting $\ln \left(\mathrm{C}_{\mathrm{o}} / \mathrm{C}_{\mathrm{t}}\right)$ against $\mathrm{t}$ in decolorization reaction at various initial Orange II concentrations $(0.1-0.4 \mathrm{mM})$ in $5 \mathrm{mM}$ citric acid is shown in Figure 4(a). Table 2 shows the first-order reaction rate constants and the initial reaction rates $\left(\mathrm{v}_{\mathrm{o}}\right)$ calculated by the following equation.

$$
v_{o}=(-d C / d t)_{t=0}=k_{o b s} C_{o}
$$

The reactions obeyed first-order reaction model in these dye concentrations. The first-order reaction rate constants were slightly decreased with increase in the initial Orange II concentration as shown in Table 2. For the surface processes the reaction rate can be described by the Langmuir-Hinshelwood model (L-H model) which is expressed in the following equation (Mielczarski et al., 2005).

$$
1 / v_{o}=1 / k_{\text {app }}+1 /\left(k_{\text {app }} K_{m} C_{o}\right)
$$

,where $k_{\text {app }}$ and $\mathrm{K}_{\mathrm{m}}$ are apparent reaction rate constant and adsorption equilibrium constant, respectively. According to the equation 5, the reciprocal plots of initial reaction rate and initial dye concentration are linear as shown in Figure 4(b). The reciprocals of first-order reaction rate constants were reported to be proportional to initial concentrations in L-H model (Heredia et al., 2001) and the similar result was obtained in this study as shown in Figure 5. This relation is yielded by substituting $\mathrm{v}_{\mathrm{o}}$ in equation 4 into equation 5 .
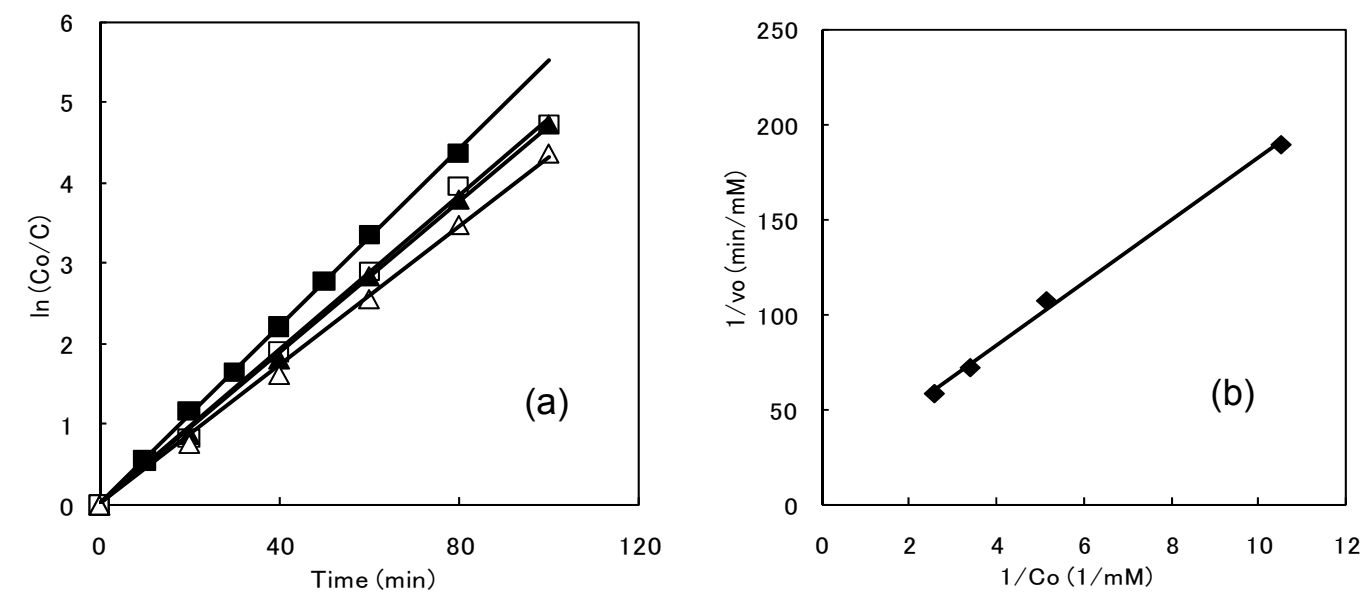

Figure 4. The plots of $\ln (\mathrm{Co} / \mathrm{C})$ against time at various initial Orange II concentrations $C_{0}(\mathbf{m}: 0.1, \square: 0.2 \boldsymbol{\Delta}$ : $0.3, \triangle: 0.4 \mathrm{mM})(\mathrm{a})$, and reciplocal plot of initial reaction rate $1 / \mathrm{v}_{\mathrm{o}}$ against $1 / \mathrm{C}_{\mathrm{o}}(\mathrm{b}) \mathrm{in}$ tin $/ 5 \mathrm{mM}$ citric acid system 
Table 2. First-order reaction rate constants $\left(\mathrm{k}_{\mathrm{obs}}\right)$ and initial reaction rates $\left(\mathrm{v}_{\mathrm{o}}\right)$ estimated from first-order reaction profile in different initial Orange II concentrations (Co) in $5 \mathrm{mM}$ citric acid

\begin{tabular}{ccc}
\hline Co $[\mathrm{mM}]$ & $\mathrm{k}_{\mathrm{obs}}\left[\mathrm{min}^{-1}\right]$ & $\mathrm{v}_{\mathrm{o}}\left[\mathrm{mM} \mathrm{min}{ }^{-1}\right]$ \\
\hline 0.1 & $5.4 \times 10^{-2}$ & $5.3 \times 10^{-3}$ \\
0.2 & $4.8 \times 10^{-2}$ & $9.3 \times 10^{-3}$ \\
0.3 & $4.7 \times 10^{-2}$ & $1.4 \times 10^{-2}$ \\
0.4 & $4.3 \times 10^{-2}$ & $1.7 \times 10^{-2}$ \\
\hline
\end{tabular}

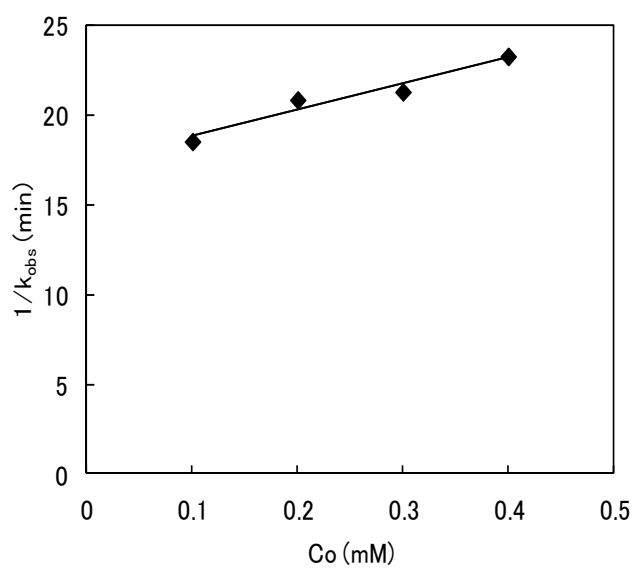

Figure 5. The plots of $1 / \mathrm{k}_{\mathrm{obs}}$ against $\mathrm{C}_{\mathrm{o}}$ in tin $/ 5 \mathrm{mM}$ citric acid system
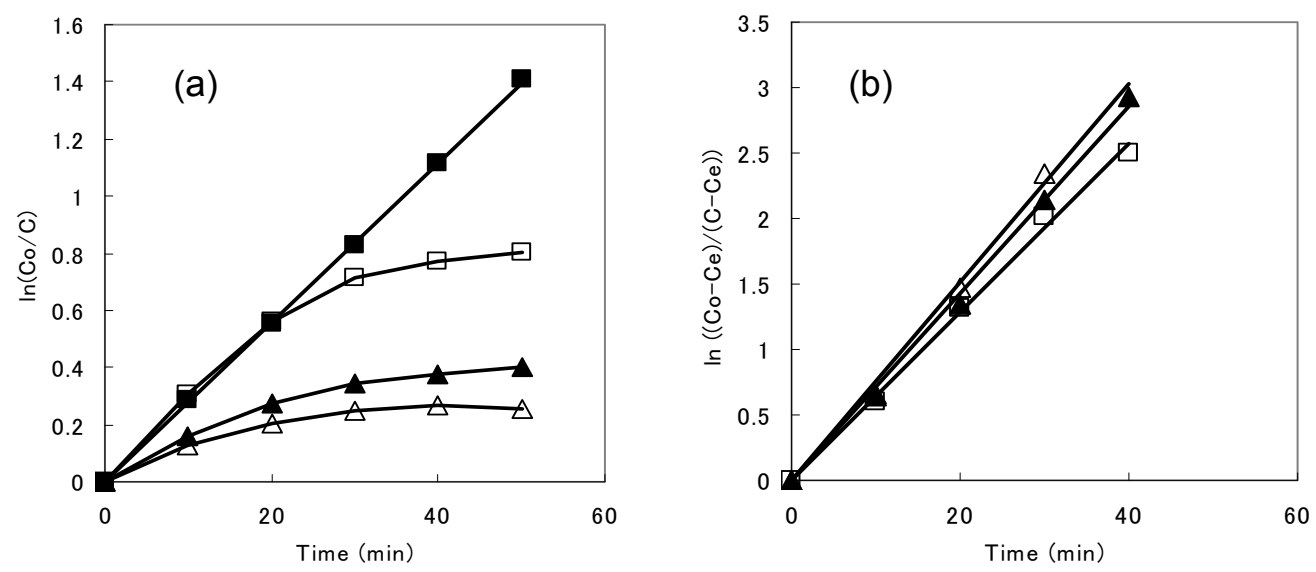

Figure 6. The plots of $\ln (\mathrm{Co} / \mathrm{C})$ against time at various initial Orange II concentrations $\mathrm{C}_{\mathrm{o}}(\mathbf{\square}: 0.1, \square: 0.2, \mathbf{\Delta}$ : $0.3, \triangle: 0.4 \mathrm{mM})(\mathrm{a})$, and the plots of $\ln ((\mathrm{Co}-\mathrm{Ce}) /(\mathrm{C}-\mathrm{Ce}))$ against time (b) in tin $/ 5 \mathrm{mM}$ hydrochloric acid system

Figure 6(a) shows the plotting of $\ln \left(\mathrm{C}_{\mathrm{o}} / \mathrm{C}_{\mathrm{t}}\right)$ against $\mathrm{t}$ at various initial Orange II concentrations $(0.1-0.4 \mathrm{mM})$ in 5 $\mathrm{mM}$ hydrochloric acid. Although straight line was obtained at $0.1 \mathrm{mM} \mathrm{C}_{0}$, the plots in the range of 0.2-0.4 mM did not give straight lines. Thus, we applied the following relaxation first-order kinetic in which the rate is expressed by first-order reaction against the difference between the concentration at time $t, C_{t}$ and the concentration at equilibrium state, $\mathrm{C}_{\mathrm{e}}$ (Hemalathe and Noorbatcha, 1997).

$$
-d C / d t=k_{o b s}\left(C_{t}-C_{e}\right)
$$




$$
\ln \left\{\left(C_{o}-C_{e}\right) /\left(C_{t}-C_{e}\right)\right\}=k_{o b s} t
$$

The model explains that the reaction proceeds toward the equilibrium state in reversible reaction (see section 3.3).

The equilibrium concentrations $\mathrm{C}_{\mathrm{e}}$ were estimated using Guggenheim method as follows.

$$
\begin{aligned}
& \left(C_{t}-C_{e}\right) /\left(C_{t+T}-C_{e}\right)=e^{k T} \\
& C_{t}=C_{e}\left(1-e^{k T}\right)+e^{k T} C_{t+T}
\end{aligned}
$$

,where $\mathrm{T}$ is a constant interval time, and the value of $10 \mathrm{~min}$ was arbitrarily chosen in this study. By plotting $\mathrm{C}_{\mathrm{t}}$ against $\mathrm{C}_{\mathrm{t}+\mathrm{T}}$, the straight lines for $0.2-0.4 \mathrm{mM}$ initial concentrations of Orange II were obtained as shown in Figure 7. The values of $\mathrm{C}_{\mathrm{e}}$ estimated from the intercepts and the slopes of the lines of equation 9 are shown in Table 3 for each $C_{o}$. Figure $6(b)$ shows the plotting of $\ln \left(\left(\mathrm{C}_{\mathrm{o}}-\mathrm{C}_{\mathrm{e}}\right) /\left(\mathrm{C}_{\mathrm{t}}-\mathrm{C}_{\mathrm{e}}\right)\right)$ versus $\mathrm{t}$. The validity of this model was proved in that the correlation coefficients $\mathrm{R}^{2}$ of the linear regressions were more than 0.995 . The first-order-reaction rate constants determined from the slopes of the lines and the initial reaction rates estimated by the following equation are shown in Table 3 .

$$
v_{o}=(-d C / d t)_{t=0}=k_{o b s}\left(C_{o}-C_{e}\right)
$$

Initial reaction rates were similar in the range of $0.2-0.4 \mathrm{mM}$ of initial Orange II concentrations.

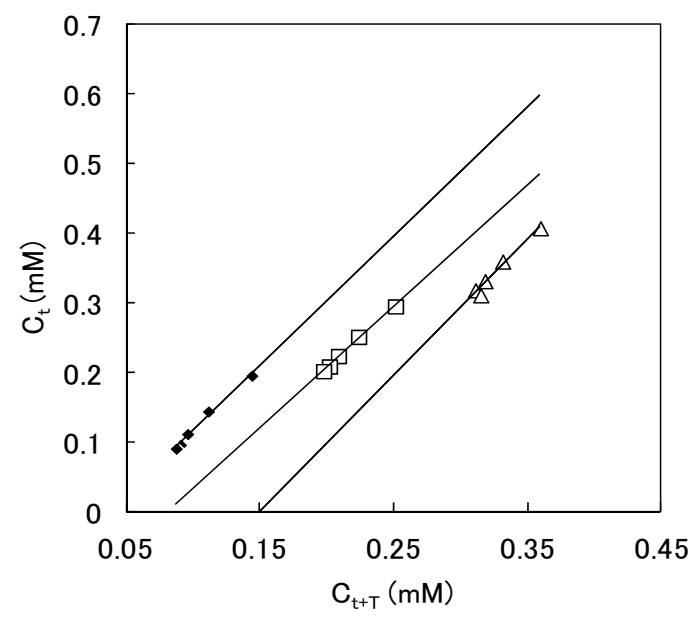

Figure 7. The plots of $C_{t}$ against $C_{t+T}$ at initial OrangeII concentrations of $0.2 \mathrm{mM}(\diamond), 0.3 \mathrm{mM}(\square)$, and $0.4 \mathrm{mM}$ $(\triangle)$ during decolorization reaction with tin/5mM hydrochloric acid system

Table 3. First-order reaction rate constants $\left(\mathrm{k}_{\mathrm{obs}}\right)$, and equilibrium concentrations $(\mathrm{Ce})$ estimated from the Guggenheim method in different initial Orange II concentrations in $5 \mathrm{mM}$ hydrochloric acid

\begin{tabular}{cccc}
\hline $\begin{array}{c}\mathrm{Co} \\
{[\mathrm{mM}]}\end{array}$ & $\begin{array}{c}\mathrm{Ce} \\
{[\mathrm{mM}]}\end{array}$ & $\begin{array}{c}\mathrm{k}_{\mathrm{obs}} \\
{\left[\mathrm{min}^{-1}\right]}\end{array}$ & $\begin{array}{c}\mathrm{v}_{\mathrm{o}} \\
{\left[\mathrm{mM} \mathrm{min}^{-1}\right]}\end{array}$ \\
\hline 0.2 & $8.1 \times 10^{-2}$ & $6.4 \times 10^{-2}$ & $7.3 \times 10^{-3}$ \\
0.3 & $1.9 \times 10^{-1}$ & $7.2 \times 10^{-2}$ & $7.5 \times 10^{-3}$ \\
0.4 & $3.1 \times 10^{-1}$ & $7.6 \times 10^{-2}$ & $7.5 \times 10^{-3}$ \\
\hline
\end{tabular}

\subsection{Reaction Mechanisms in Citric and Hydrochloric Acids}

The comparative kinetics described in the section 3.2 allows us to propose the different pathways in the reactions 
in citric and hydrochloric acids.

In the reduction of azo dyes, aromatic amines were produced through hydrazo intermediates (Zbaida et al., 1989; Nam \& Tratnyek, 2000; Chang et al., 2001; Cheng \& Wu, 2003) and thus the reductive cleavage of azo dyes was speculated to proceed through two steps as follows.

$$
\begin{gathered}
R_{1}-N=N-R_{2}+2 H^{+}+2 e^{-} \rightleftarrows R_{1}-N H-N H-R_{2} \\
R_{1}-N H-N H-R_{2}+2 H^{+}+2 e^{-} \rightarrow R_{1}-N H_{2}+R_{2}-N H_{2}
\end{gathered}
$$

Decolorization reaction in citric acid obeyed a first-order kinetic over the examined range of dye concentrations. In addition, L-H model, which explained that the overall rate was controlled by the tin surface reaction in citric acid, was applicable. This indicates the reduction steps of (11) and (12) were consecutively and rapidly occurred on tin surface. Dissolution of tin in citric acid $\left(\mathrm{H}_{2} \mathrm{Cit}\right)$ is accompanied by the following reactions (Almeida and Giannettii, 2001).

$$
\begin{gathered}
\mathrm{Sn}^{2+}+\mathrm{H}_{2} \mathrm{Cit}^{-} \rightarrow \mathrm{SnCit}+2 \mathrm{H}^{+} \\
\mathrm{SnCit}+\mathrm{H}^{+} \rightarrow \mathrm{SnHCit} \\
\mathrm{SnHCit}+2 \mathrm{H}_{2} \mathrm{O} \rightarrow \mathrm{SnO}_{2}+\mathrm{H}_{2} \mathrm{Cit}^{-}+2 e^{-}+3 \mathrm{H}^{+}
\end{gathered}
$$

Dissolved ion of $\mathrm{Sn}^{2+}$ in citric acid formed a complex of Sn (II) - citrate (SnCit). The protonated complex (SnHCit) adsorbed on the surface of tin was oxidized to $\mathrm{SnO}_{2}$ and four electrons were liberated during the reactions. The generated electrons would be rapidly transferred to azo dye, leading to rapid reduction to aromatic amines. The scheme described above is summarized in Figure 8. In our previous study on the decolorization of azo dyes by tin-immobilized material, the adsorption of a complex $\mathrm{Sn}$ (II)-citrate and the formation of $\mathrm{SnO}_{2}$ on tin surface were confirmed (Nishide et al., 2010).

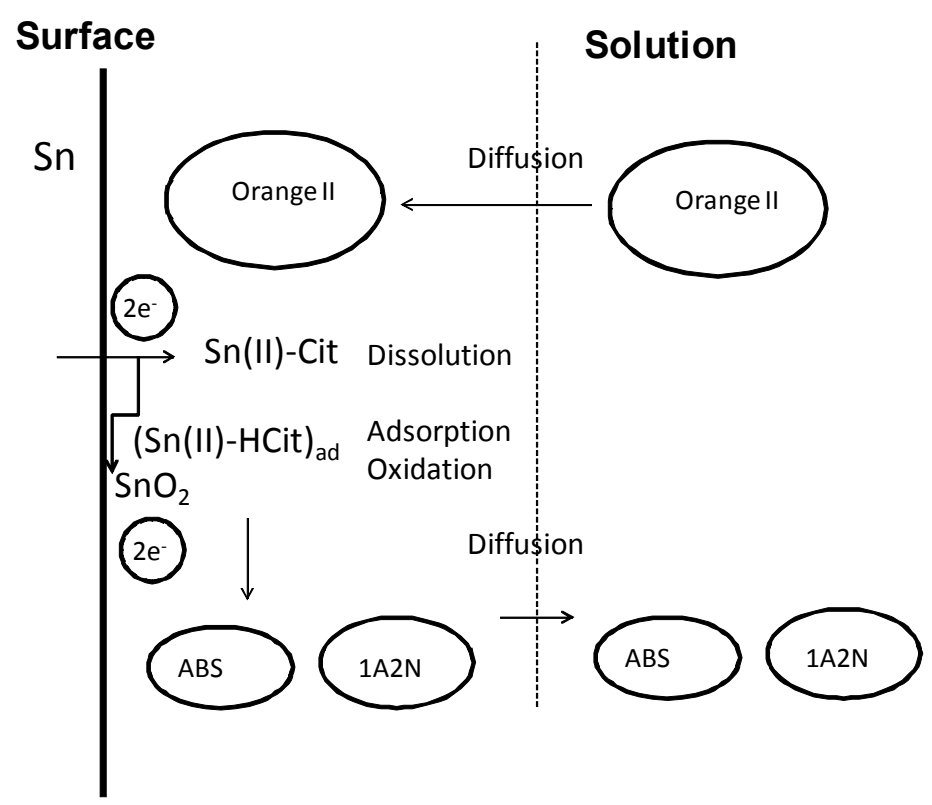

Figure 8. A scheme of decolorization of Orange II by tin in citric acid

When the initial concentration of Orange II was more than $0.2 \mathrm{mM}$ in hydrochloric acid, the reaction kinetics were expressed by the equation 6 which introduced the equilibrium concentration. Figure 9 shows a scheme of Orange II decolorization in hydrochloric acid by introducing the reversible reaction (11) where hydrazo intermediate returned to the parent compound. In the higher concentrations of Orange II, the diffusion of the 
produced hydrazo intermediate into solution would be significant and the hydrazo intermediate is readily reoxidized to azo compound by the oxidants like oxygen (Zimmermann et al., 1982). Thus, the further reduction of hydrazo intermediate by tin surface is retarded and pseudo-first-order reaction kinetic was not applicable. Other possibilities for deviation from first-order kinetic are that dissolved $\mathrm{Sn}^{2+}$ reduces the hydrazo intermediate in solution as shown in bracket in Figure 9 or that the diffusion of $\mathrm{Sn}^{2+}$ into solution may be prohibited by adsorbed dye on the tin and thus the reduction of hydrazo intermediate would be reduced in higher dye concentrations.

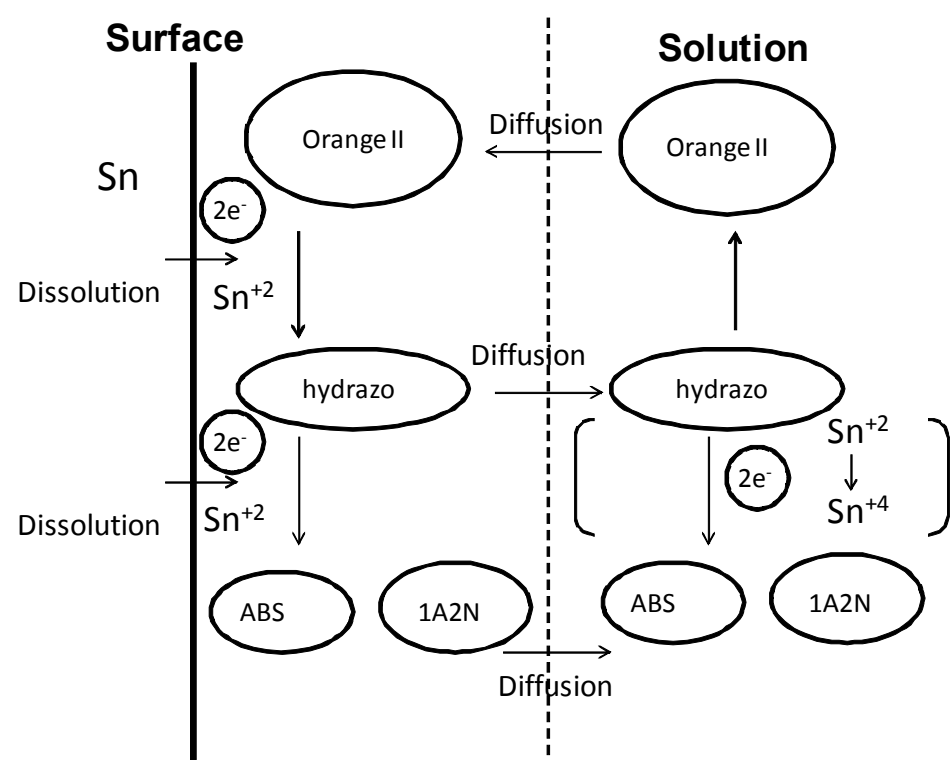

Figure 9. A scheme of the decolorization of Orange II by tin in hydrochloric acid.

A plausible reduction of hydrazo intermediate by stannous ion is shown in brackets

\subsection{Effect of $p H$ in Citrate Buffer}

The effect of $\mathrm{pH}$ on the decolorization rate of $0.1 \mathrm{mM}$ Orange II was investigated in $5 \mathrm{mM}$ citrate buffer. The decolorization kinetics at various pHs are shown in Figure 10. The first-order-reaction model was applicable at $\mathrm{pH}$ less than 4 but the reaction rates were not so different. The decolorization rates significantly decreased at $\mathrm{pH}$ 4.5 and almost no reaction occurred at $\mathrm{pH}$ 5. The significant decrease in the decolorization at $\mathrm{pH} 5 \mathrm{was}$ presumably due to notable decrease in dissolution rate of tin at pH 5 (Gouda et al., 1981).

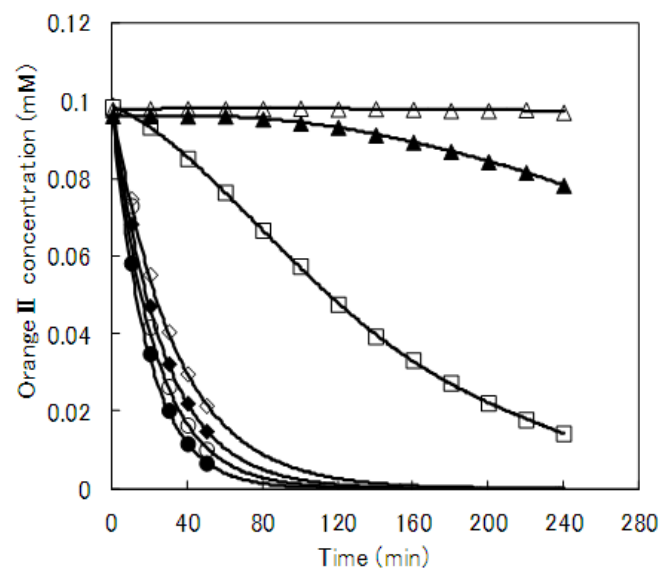

Figure 10. The time course of the decolorization of Orange II at various $\mathrm{pH}$ values in tin/citrate buffer system.

$\bullet: \mathrm{pH} 2.8, \circ: \mathrm{pH} 3, \diamond: \mathrm{pH} 3.5, \diamond: \mathrm{pH} 4, \square: \mathrm{pH} 4.5, \boldsymbol{\Delta}: \mathrm{pH} 5, \triangle: \mathrm{pH} 5.5$ 
The BET surface area normalized rate constant was calculated as $\mathrm{k}_{\mathrm{SA}}=0.25 \mathrm{~lm}^{-2} \min ^{-1}$ (citrate buffer $5 \mathrm{mM}$, pH 3). The BET surface area normalized rate constant for decolorization of Orange II by zero-valence iron was reported to be $\mathrm{k}_{\mathrm{SA}}=0.18 \mathrm{~lm}^{-2} \mathrm{~min}^{-1}$ at $\mathrm{pH} 3$ (Mielczarsky et al., 2005). Although iron has higher standard reducing potential $\left(\mathrm{Fe}^{2+}+2 \mathrm{e}^{-}=\mathrm{Fe}:-0.44 \mathrm{~V}\right)$ than tin $\left(\mathrm{Sn}^{2+}+2 \mathrm{e}^{-}=\mathrm{Sn}:-0.138 \mathrm{~V}\right)$, tin/citrate system showed higher reaction rate constant than that of iron in this experiment. This suggests that citrate played an important role in the enhanced decolorization reaction of Orange II.

\subsection{Repeated Decolorization of Orange II}

Repeated decolorization of Orange II was carried out in $2.5 \mathrm{mM}$ citric acid and $10 \mathrm{mM}$ hydrochloric acid in which both solution $\mathrm{pH}$ values are shown in Table 1. In these acid concentrations, the almost complete decolorization ratios were obtained in the first $50 \mathrm{~min}$. Decolorization ratios and pseudo-first-order reaction rate constants in each of 50-min repeated reaction are shown in Table 4.

Table 4. Decolorization ratios and first-order reaction rate constants $\left(\mathrm{k}_{\mathrm{obs}}\right)$ at each 50 min cycle in 5 repeated decolorizations in $2.5 \mathrm{mM}$ citric acid and in $10 \mathrm{mM}$ hydrochloric acid at initial concentration of Orange II of $0.1 \mathrm{mM}$

\begin{tabular}{ccccc}
\hline & \multicolumn{2}{c}{ Decolorization ratio [\%] } & \multicolumn{2}{c}{$\mathrm{k}_{\text {obs }}\left[\mathrm{min}^{-1}\right]$} \\
Cycle & Hydrochloric acid & Citric acid & Hydrochloric acid & Citric acid \\
& $10 \mathrm{mM}$ & $2.5 \mathrm{mM}$ & $10 \mathrm{mM}$ & $2.5 \mathrm{mM}$ \\
\hline 1 & 98 & 93 & $7.6 \times 10^{-2}$ & $5.7 \times 10^{-2}$ \\
2 & 92 & 92 & $5.1 \times 10^{-2}$ & $5.0 \times 10^{-2}$ \\
3 & 87 & 94 & $4.0 \times 10^{-2}$ & $5.1 \times 10^{-2}$ \\
4 & 86 & 92 & $4.0 \times 10^{-2}$ & $5.3 \times 10^{-2}$ \\
5 & 86 & 92 & $3.8 \times 10^{-2}$ & $5.3 \times 10^{-2}$ \\
\hline
\end{tabular}

Decolorization ratios and pseudo-first-order reaction rate constants in citric acid were not affected by repeated reactions, but the reaction rate constant in the fifth cycle in hydrochloric acid was half of the value in the first decolorization.

The dissolved $\mathrm{Sn}^{2+}$ is easily oxidized to $\mathrm{Sn}^{4+}$ and $\mathrm{Sn}^{4+}$ is hydrolyzed in acid media to form the highly insoluble $\mathrm{Sn}(\mathrm{OH})_{4}$ and $\mathrm{SnO}_{2}$, which are precipitated on the surface of tin to form oxide film (Hassan and Fahmy, 2008). The formation of oxide film blocks the active site of tin, leading to reduced reaction. In hydrochloric acid in this study half-decrease in reaction rate constant was observed in 5-th repeated use and this was due to the oxide film formation to inhibit the dissolution of tin (Stirrup and Hampson, 1976). However, decolorization was successfully repeated in almost the same rate in citric acid as shown in Table 4. It is known that the oxide film formed in citrate solution was thin and conductive for electron transfer (Giannetti, 1990; Séruga and Metikoš-Huković, 1992; Abdel Rehim, 2003). Therefore, the tin oxide film in citric acid was not so influential to disturb dissolution of tin and decolorization activity of tin.

The result that tin/citric acid system exhibited the successful decolorization in repeated use suggests the possibility of its application for actual system as a heterogeneous process alternative to anaerobic biological treatment. This study was performed in laboratory scale and then we could not discuss the cost efficiency of tin/citric acid system compared to anaerobic biological decolorization in actual scale. Laboratory-scale anaerobic bioreactor in fed-batch repeated decolorizations of Orange II took 8-20 days for the complete decolorization of $0.06 \mathrm{mM}$ Orange II in one cycle (Mèndez-Paz et al., 2005). Van der Zee et al. (2001) reported that first-order reaction rate constant was $1.0 \times 10^{-3} \mathrm{~min}^{-1}$ in the decolorization of $0.3 \mathrm{mM}$ Orange II with anaerobic granular sludge which was about one-twentieth of our result and anaerobic bacterial culture needs thermal control to maintain moderate temperature and electron-donating carbon sources for the high decolorization (Pearce et al., 2003). Although, detail cost analysis is not available in actual system at this stage, high decolorization rate and cut-off of the energy cost of heating in the decolorization treatment by tin/citrate system will be advantageous.

\section{Conclusions}

In the decolorization kinetics of Orange II by zero-valence tin in citric acid and in hydrochloric acid solutions, 
the decolorization rate in citric acid was faster compared with in hydrochloric acid. As the OCP values in citric acid were negatively higher than in hydrochloric acid, the reducing power of tin in citric acid was stronger than in hydrochloric acid, leading to the enhancement of reduction of azo dye in citric acid. The first-order kinetic was applicable in citric acid over the examined range of the initial Orange II concentrations. The fast reaction in tin/citrate system was mainly due to the formation a complex of Sn (II)-citrate and its subsequent oxidation to $\mathrm{SnO}_{2}$. The relaxation first-order kinetic was applicable in hydrochloric acid considering hydrazo intermediate formation. Tin/citric acid system showed no decline in the decolorization activity in repeated use, leading to the feasibility as a novel heterogeneous decolorization process.

\section{References}

Abdel Rehim, S. S., Sayyah, S. M., \& El Deeb, M. M. (2003). Corrosion of tin in citric acid solution and the effect of some inorganic anions. Materials Chemistry and Physics, 80, 696-703. http://dx.doi.org/10.1016/S0254-0584(03)00128-7

Almeida, C. M. V. B., \& Giannetti, B. F. (2001). Protective film growth on tin in perchlorate and citric acid $\begin{array}{lllll}\text { electrolytes. Materials Chemistry and } & \text { 261-266. }\end{array}$ http://dx.doi.org/10.1016/S0254-0584(00)00458-2

Cao, J., Wei, L., Huang, Q., Wange, L., \& Han, S. (1999). Reduction degradation of azo dye by zero-valent iron in aqueous solution. Chemosphere, 38, 565-571. http://dx.doi.org/10.1016/S0045-6535(98)00201-X

Chang, J. H., Chou, C., Lin, Y. C., Lin, P. J., \& Ho, J. Y. (2001). Kinetic characterization of bacterial azo-dye decolorization by Pseudomonas luteora. Water Research, 13, 2841-2850. http://dx.doi.org/10.1016/S0043-1354(00)00581-9

Chang, M. C., Shu, H. Y., Yu, H. H., \& Sung, Y. Y. (2006). Reductive decolorization and total organic carbon reduction of the diazo dye CI Acid black 24 by zero-valent iron powder. Journal of Chemical Technology and Biotechnology, 81, 1259-1266. http://dx.doi.org/10.1002/jctb.1543

Cheng, S. F., \& Wu, S. C. (2003). The enhancemet methods for the degradation of TCE by zero-valent metals. Chemosphere, 41, 1263-1270. http://dx.doi.org/10.1016/S0045-6535(99)00530-5

Choi, J. H., \& Kim, Y. H. (2009). Reduction of 2,4,6-trichlorophenol with zero-valent zinc and catalyzed zinc. Journal of Hazardous Materials, 166, 984-991. http://dx.doi.org/10.1016/j.jhazmat.2008.12.004

Delée, W., O’ Neill, C., Hawkes, F. R., \& Pinheiro, H. M. (1998). Anaerobic treatment of textile effluents: a review. Journal of Chemical Technology and Biotechnology, 73, 323-335. http://dx.doi.org/10.1002/(SICI)1097-4660(199812)73:4<323::AID-JCTB976>3.0.CO;2-S

Feng, W., Nansheng, D., \& Helin, H. (2000). Degradation mechanism of azo dye C. I. Reactive red 2 by iron powder reduction and photooxidation in aqueous solutions. Chemosphere, 41, 1233-1238. http://dx.doi.org/10.1016/S0045-6535(99)00538-X

Giannetti, B. F., Sumodjo, P. T. A., \& Rabockai, T. (1990). Electrochemical studies with tin electrodes in citric acid solutions. Journal of Applied Electrochemistry, 20, 672-676. http://dx.doi.org/10.1007/BF01008881

Gouda, V. K., Rizkalla, E. N., Abd-el-wahab, S., \& Ibrahim, E. M. (1981). Corrosion behavior in organic acid solutions-I. Tin electrode. Corrosion Science, 21, 1-15. http://dx.doi.org/10.1016/0010-938X(81)90058-5

Hassan, H. H., \& Fahmy, K. (2008). Pitting corrosion of tin by acetate anion in acidic media. International Journal of Electrochemical Science, 3, 29-43.

Hemalatha, M. R. K., \& Noorbatcha, I. (1997). An undergraduate physical chemistry experiment on the analysis of first-order kinetic data. Journal of Chemical Education, 74, 972-974. http://dx.doi.org/10.1021/ed074p972

Heredia, J. B. D., Torregrosa, J., Dominguez, J. R., \& Peres, J. A. (2001). Oxidation of $p$-hydoroxybenzoic acid by UV radiation and by $\mathrm{TiO}_{2} / \mathrm{UV}$ radiation: comparison and modeling of reaction kinetic. Journal of Hazardous Materials, B83, 255-264. http://dx.doi.org/10.1016/S0304-3894(01)00194-7

Mannu, B., \& Chaudhari, S. (2002). Anaerobic decolorization of stimulated textile wastewater containing azo dyes. Bioresource Technology, 82, 225-231. http://dx.doi.org/10.1016/S0960-8524(01)00190-0

Mèndez-Paz, F., Omil, F., \& Lema, J. M. (2005). Anaerobic treatment of azo dye Acid orange 7 under fed-batch and continuous conditions. Water research, 39, 771-778. http://dx.doi.org/10.1016/j.watres.2004.11.022

Mielczarsky, J. A., Montes Atenas, G., \& Mielczarski, E. (2005). Role of iron surface oxidation layers in 
decomposition of azo-dye water pollutants in weak acidic solutions. Applied Catalysis B: Environmental, 56, 289-303. http://dx.doi.org/10.1016/j.apcatb.2004.09.017

$\mathrm{Mu}$, Y., Zhang, S. J., \& Zhen, J. C. (2004). Kinetics of reductive degradation of Orange II in aqueous solution by zero-valent iron. Journal of Chemical Technology and Biotechnology, 79, 1429-1431. http://dx.doi.org/10.1002/jctb.1136

Nam, S., \& Tratnyek, P. G. (2000). Reduction of azo dyes with zero-valent iron. Water Research, 34, 1837-1845. http://dx.doi.org/10.1016/S0043-1354(99)00331-0

Nishide, S., Hirai, M., \& Shoda, M. (2010). Decolorization of azo dyes by PIP tin balls in citric acid solution. Journal of Water and Environment Technology, 8, 85-98. http://dx.doi.org/10.2965/jwet.2010.85

Nishide, S., \& Shoda, M. (2011). Biodegradation of aromatic amines produced from the decolorization of Orange II by zero-valence tin. Journal of Water and Environment Technology, 9, 89-100. http://dx.doi.org/10.2965/jwet.2011.89

Pearce, C. I., Lloyd, J. R., \& Guthrie, J. T. (2003). The removal of colour from textile wastewater using whole $\begin{array}{lllll}\text { bacterial cells: a review. Dyes and Pigments, } & \text { 179-196. }\end{array}$ http://dx.doi.org/10.1016/S0143-7208(03)00064-0

Robinson, T., McMullan, G., Marchant, R., \& Nigam, P. (2001). Remediation of dyes in textile effluents: a critical review on current treatment technologies with the proposed alternative. Bioresource Technology, 77, 247-255. http://dx.doi.org/10.1016/S0960-8524(00)00080-8

Rodríguez Couto, S., Domíguez, A., \& Sanromán, A. (2002). Photocatalytic degradation of dyes in aqueous solution operating in fluidised bed reactor. Chemosphere, 46, 83-86. http://dx.doi.org/10.1016/S0045-6535(01)00130-8

Séruga, M., \& Metikoš-Huković, M. (1992). Passivation of tin in citrate buffer solutions. Journal of Electroanalytical Chemistry, 334, 223-240. http://dx.doi.org/10.1016/0022-0728(92)80574-N

Shaul, G. M., Holdsworth, T. J., \& Dempsey, C. R. (1991). Fate of water soluble azo dyes in the activated sludge process. Chemosphere, 22, 107-119. http://dx.doi.org/10.1016/0045-6535(91)90269-J

Stirrup, B. N., \& Hampson, N. A. (1976). The active dissolution of tin in acidic chloride electrolyte solutions - a rotating disc study. Journal of Applied Electrochemistry, 6, 353-360. http://dx.doi.org/10.1007/BF00608921

Vandervivere, P. C., Bianchi, R., \& Verstrate, W. (1998). Treatment and reuse of wastewater from the textile wet-processing industry: Review of emerging technology. Journal of Chemical Technology and Biotechnology, 72, 289-302. http://dx.doi.org/10.1002/(SICI)1097-4660(199808)72:4<289::AID-JCTB905>3.0.CO;2-\#

Van der Zee, F. P., Lettinga, G., \& Field, J. A. (2001). Azo dye decolorization by anaerobic granular sludge. Chemosphere, 44, 1169-1176. http://dx.doi.org/10.1016/S0045-6535(00)00270-8

Van der Zee, F. P., \& Villaverde, S. (2005). Combined anaerobic-aerobic treatment of azo dye-a short review. Water Research, 39, 1423-1440. http://dx.doi.org/10.1016/j.watres.2005.03.007

Young, L., \& Yu, J. (1997). Ligninase-catalysed decolorization of synthetic dyes. Water Research, 31, 1187-1193. http://dx.doi.org/10.1016/S0043-1354(96)00380-6

Zbaida, S., Stoddart, A. M., \& Levine, W. G. (1989). Studies on the mechanism of reduction of reduction of azo dye carcinogens by rat liver microsomal cytochrome P-450. Chemico-Biological Interactions, 69, 61-71. http://dx.doi.org/10.1016/0009-2797(89)90099-9

Zhang, H., Duan, L., Zhang, Y., \& Wu, F. (2005). The use of ultrasound to enhance the decolorization of the C.I. Acid Orange 7 by zero-valent iron. Dyes and Pigments, 65, 39-43. http://dx.doi.org/10.1016/j.dyepig.2004.06.015

Zimmermann, T., Kulla, H. G., \& Leisinger, T. (1982). Properties of purified Orange II azoreductase, the enzyme initiating azo dye degradation by Pseudomonas KF46. European Journal of Biochemistry, 129, 197-203. http://dx.doi.org/10.1111/j.1432-1033.1982.tb07040.x 